\title{
Endogenous auxin and cytokinin contents associated with shoot formation in leaves of pineapple cultured in vitro
}

\author{
Helenice Mercier ${ }^{*}$, Beatriz Maia Souza², Jane Elizabeth Kraus², Regina Mayumi Hamasaki² and Bruno Sotta ${ }^{3}$ \\ ${ }^{1}$ Departamento de Botânica, Instituto de Biociências, Universidade de São Paulo, CP 11461, CEP 5422-970, São Paulo, SP, Brasil; \\ ${ }^{2}$ Laboratoire de Physiologie du Developpement des Plantes, Université Pierre-et-Marie-Currie, Place Jussieu, 75252 Paris Cedex 05, \\ France; *Corresponding author: hmercier@usp.br \\ Received: 17/02/2003, Accepted: 08/05/2003
}

The in vitro culture of pineapple leaves on a shoot induction medium (SIM) results in the formation of protuberances and further development in shoots, and plantlets. The contents of endogenous indoleacetic acid (IAA) and five cytokinins (Cks), $\mathrm{N}^{6}$ (2-isopentenyl)adenine (iP), $\mathrm{N}^{6}$ (2-isopentenyl)adenosine (iPR), zeatin (Z), zeatin riboside (ZR) and $\mathrm{N}^{6}$-benzyladenine (BA), present in the basal portion of those leaves, were correlated to the organogenic response that occurs over 15 days of culture. The endogenous auxin/cytokinins ratio was lowest on the $3^{\text {rd }}$ day, mainly due to a strong increase in the iP level. It seems that endogenous iP concentration triggered the induction signal for an organogenic response in pineapple leaf bases. The rise in iP content required the presence of BA and $\alpha$-naphthaleneacetic acid (NAA) in the medium, suggesting that endogenous iP production is regulated in response to these growth regulator uptakes.

Key words: Ananas comosus, auxin, Bromeliaceae, cytokinin, hormone signalling, plant regeneration.

Teores endógenos de auxina e citocininas associados à formação de eixos caulinares em folhas de abacaxizeiro cultivadas in vitro: A cultura in vitro de folhas de abacaxizeiro em meio de indução de eixos caulinares (SIM) resulta na formação de protuberâncias e, posteriormente, no desenvolvimento de eixos caulinares e de plantas. Os teores endógenos de ácido idolilacético (AIA) e de cinco citocininas, $\mathrm{N}^{6}$ (2-isopenteniladenina (iP), $\mathrm{N}^{6}$ (2-isopenteniladenosina (iPR), zeatina (Z), zeatina ribosídica $(\mathrm{ZR})$ e $\mathrm{N}^{6}$-benziladenina (BA), presentes na porção basal dessas folhas, foram correlacionados à resposta organogenética que ocorre durante o período de 15 dias de cultivo. Uma intensa redução do balanço endógeno entre auxina/citocininas ocorreu no 3o dia de cultivo, em função, principalmente, de grande incremento no conteúdo de iP. Sugere-se que a concentração endógena de iP tenha desencadeado a sinalização indutora da resposta organogenética das bases foliares do abacaxizeiro. O aumento no teor de iP depende da presença conjunta de BA e do ácido naftalenoacético (ANA) no meio de cultura, indicando que a produção endógena de iP é regulada em resposta à absorção desses reguladores de crescimento.

Palavras-chave: Ananas comosus, auxina, Bromeliaceae, citocinina, sinalização hormonal, regeneração de planta.

\section{INTRODUCTION}

Both rhizogenesis and caulogenesis occur in some plant cells or tissue culture as a response to the manipulation of exogenous levels in growth regulators (Skoog and Miller, 1957). In a wide range of species, the production of shoots or roots in vitro is controlled by the auxin/cytokinin ratio. According to Christianson and Warnick (1985), organogenesis can be divided into three phases: 1) acquisition of competence, i.e., the ability to respond to organogenic induction; 2) organogenic indution per se, during which the cells become determined for specific organ formation; and 3) morphological differentiation and development, resulting in visible roots or shoots. These authors were the first to demonstrate that the control of the type of organogenesis by the balance of exogenous hormones, resides in the induction phase. Only during this period is the hormonal composition of the medium critical.

Lakshmanan et al. (1997) analysed the states of competence, induction and differentiation associated with the direct shoot regeneration system using leaf explants of a 
tropical fruit tree, Garcinia mangostana. In this study it was noted that the cytokinin (BA) treatment is required during the induction period of six days for fully competent cells to enter into a caulogenically determined state.

It has been reported that exogenous BA may act either directly on plant cells, or through its control of the accumulation of other cytokinin compounds. The positive effect of exogenous BA on the accumulation of iP and iPR has been described in leaf explants of Petunia hybrida in the process of shoot organogenesis (Auer et al., 1999). However, the role of endogenous hormone metabolism has not been completely defined for any developmental event in vitro (Auer et al., 1999).

Ananas comosus (pineapple) leaves cultivated in vitro represent a callus-free experimental system, and they produce a cell cluster called protuberance on their basal portion. The protuberance has a high capacity for plant or organ regeneration via organogenesis (Teng, 1997). Protuberances have been reported in pineapple leaf explants when they are cultivated in the presence of various combinations of BA and NAA (Wasaka, 1989). This experimental system represents a micropropagation method, allowing the formation of protuberances and their further development into shoots and plantlets. Furthermore, it provides a good system to study certain physiological aspects of de novo shoot bud induction in bromeliads, since other genera such as Vriesea, Dychia, Neoregelia have shown the same organogenic capacity as Ananas leaves (Mercier and Kerbauy, 1992; Mercier and Kerbauy, 1993; Carneiro et al., 1998).

In previous experiments carried out in our laboratory, a exogenous hormonal balance between NAA $\left(1.0 \mathrm{mg} . \mathrm{L}^{-1}\right)$ and BA (2.0 mg. $\left.\mathrm{L}^{-1}\right)$ was chosen as the best to induce formation of protuberances on the pineapple leaf base. The organogenic event is dependent on the presence of auxin and cytokinin in the medium, i.e., in the absence of exogenous hormones, no protuberances are formed and consequently, no shoot buds arise. The aim of this study was to measure and correlate endogenous hormonal contents for the shoot formation process that occurs in pineapple leaves cultivated in vitro. To this end, the levels of IAA and five cytokinins (Z, ZR, iP, iPR and BA) in leaf bases in different culture periods were analysed. The accompaniment of morphological alterations in leaf bases was also established over time. To our knowledge, this is the first time that phytohormone levels have been quantified and associated with shoot formation in pineapple leaf segments.

\section{MATERIAL AND METHODS}

Plant material and culture conditions: Leaves ( $7-10 \mathrm{~cm}$ long) of Ananas comosus cultivar "Smooth Cayenne" were isolated from in vitro stock plants (mother-plants) cultured on a liquid MS medium (Murashige and Skoog, 1962) containing 0.5 mg.L. ${ }^{-1}$ NAA, 0.5 mg.L $\mathrm{L}^{-1}$ BA, $0.1 \mathrm{mg} . \mathrm{L}^{-1}$ thiamine-HCl, 0.5 mg. $\mathrm{L}^{-1}$ pyridoxine- $\mathrm{HCl}, 0.5 \mathrm{mg} . \mathrm{L}^{-1}$ nicotinic acid, $4 \mathrm{mg} . \mathrm{L}^{-1}$ glycine, $100 \mathrm{mg} . \mathrm{L}^{-1}$ myo-inositol and $30 \mathrm{~g} . \mathrm{L}^{-1}$ sucrose. Each mother-plant gave 2-4 leaves. These leaves were cultured on shoot induction medium (SIM) containing macronutrients of Knudson formulation (1946), micronutrients of MS, and growth regulators NAA $\left(1.0 \mathrm{mg} . \mathrm{L}^{-1}\right)$ and BA $\left(2.0 \mathrm{mg} . \mathrm{L}^{-1}\right)$. In addition, control leaves were cultured on the same medium without growth regulators (CM). Ten leaves were inoculated into each $125 \mathrm{ml}$ Erlenmeyer flask containing $50 \mathrm{ml}$ of liquid medium. The culture flasks were incubated at $25 \pm 2^{\circ} \mathrm{C}$ under $16 \mathrm{~h}$ light provided by cool-white fluorescent lamps at 30 $\mu \mathrm{mol} . \mathrm{m}^{-2} \cdot \mathrm{s}^{-1}$. Five replications were used for each treatment. The leaves were collected at $0,3,6,9$ and 15 days of culture in vitro then superficially washed and dried.

Hormonal analysis: One leaf segment (5 mm long) was cut from the base of each leaf cultured on SIM or CM. The leaf base segments were weighed, frozen in liquid nitrogen, and stored at $-70^{\circ} \mathrm{C}$. Five endogenous cytokinins, iP, iPR, Z, ZR, $\mathrm{BA}$, and the auxin IAA were extracted, purified and quantified from leaf base segments using procedures described by Maldiney et al. (1986) and Pelèse et al. (1989). Fifty leafbase segments, approximately $300 \mathrm{mg}$ fresh mass (FM), per collection time $(0,3,6,9,15$ days) were used.

Leaf-base tissues were stirred and extracted using cold, $80 \%$ methanol, to which was added $40 \mathrm{mg} . \mathrm{L}^{-1}$ butylhydroxytoluene as an antioxidant for $60 \mathrm{~h}$ at $4^{\circ} \mathrm{C}$. Tritiated IAA and ABA (1.85 kBq/extract) were added for an estimation of recovery, since there is no commercial tritiated cytokinin available. Tritiated IAA and ABA have been shown to perform as internal standards for Z, ZR and iP, iPR, BA respectively (Maldiney et al., 1986; Sotta et al., 1987). The methanolic extracts were filtered through both $0.45 \mu \mathrm{m}$ and $0.2 \mu \mathrm{m}$ pore-size filters, and then passed through a Sep-Pack C18 cartridge eluted with $80 \%$ methanol. The eluates were reduced to water by a rotary evaporator, made to $500 \mu 1$ with diluted formic acid $(0.2 \%)$, and then purified by high performance liquid chromatography (HPLC) using an octadecyl-reversed phase column. The elution solvent was methanol in formic acid at $\mathrm{pH}$ 3.0. Triethylamine was added 
to improve cytokinin separation. The fractions were collected and reduced to dryness before being methylated with ethereal diazomethane for IAA analysis. Cytokinin and IAA quantification was carried out by means of an enzyme-linked immunosorbent assay method with polyclonal anti-ZR (crossreactivity against $Z$ ), anti-iPR (cross-reactivity against iP and BA) and anti-IAA antibodies. The level of each hormone per sample was measured 5 times, and the values were corrected for recovery. Calculations were made by reference to a calibration curve established on each microtritation plate with a $4^{\text {th }}$ order polynomial regression obtained from 4 experimental standard curves. Data for leaf base hormonal levels were based on 3 independent experiments, which gave similar results, whereas the values given in this paper are from one experimental series. Hormonal data underwent analysis of variance (ANOVA).

Histological Analysis: Four replications of leaves maintained at $0,3,6,9$ and 15 days of culture on SIM or CM were used for histological analysis. A basal segment was cut from each leaf and fixed in a solution of modified Karnovsky (1965), that is, $4 \%$ glutaraldehyde and $1 \%$ paraformaldehyde in 0.1 $\mathrm{M}$ phosphate buffer ( $\mathrm{pH}$ 7.2) at room temperature, for $4 \mathrm{~h}$. Fixed material was progressively dehydrated in ethanolic series, and embedded in historesin (Kraus and Arduin, 1997). Transverse sections were obtained with a rotary microtome and stained with toluidine blue $\mathrm{O}$ in $0.1 \mathrm{M}$ phosphate buffer (pH 6.8) (O’Brien et al., 1965).

Scanning Electron Microscopy Analysis: For scanning electron microscopy (SEM) studies, 0, 3, 6, 9 and 15-day-old leaf base segments were fixed in formalin, acetic acid and ethyl alcohol (FAA) (Johansen, 1940), dehydrated in ethanolic series, critical-point dried with $\mathrm{CO}_{2}$ and coated with goldpalladium (Silveira, 1989).

\section{RESULTS}

Organogenic response: The exogenous hormonal balance between NAA (1.0 mg. $\left.\mathrm{L}^{-1}\right)$ and BA (2.0 mg. $\left.\mathrm{L}^{-1}\right)$ was employed to induce formation of protuberances on the pineapple leaf base (figure 1). The highest percentage of cultivated leaves forming protuberances was $40 \%$, and the highest mean number of protuberance regenerating buds per leaf was 3.5 .

Some pineapple leaves clearly changed during the 15 days of culture on SIM (figure 2). These leaves at 3-6 days of culture (figure 2A), showed a swelling on the adaxial surface, in the basal region. At 9 days of culture (figure 2B), one or more protuberances in the swollen region were observed. Histological analysis (figure 2C) indicates the endogenous origin of the protuberances, which comprise meristematic cells. Intense cell division also occurred in the leaf parenchyma. On 15-day-old leaves, shoots were formed (figure 2D).

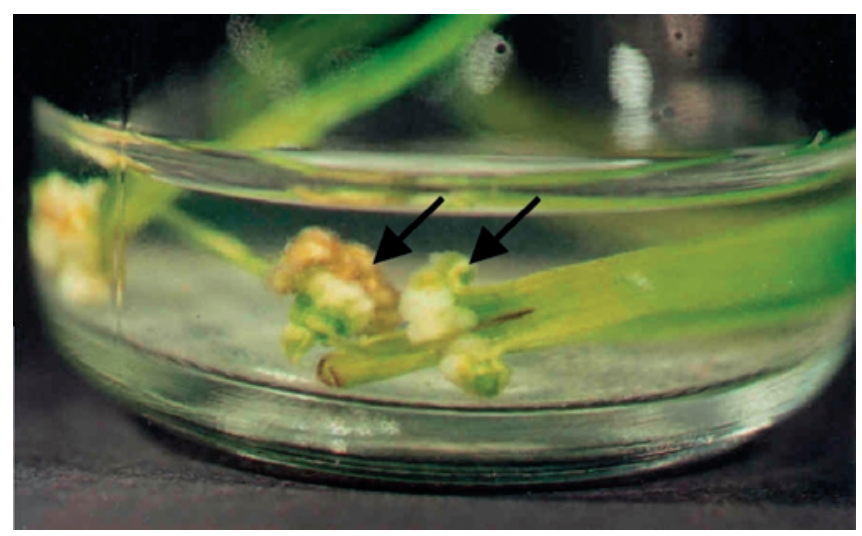

Figure 1. Protuberances (arrows) forming on the leaf basal portion after 10 days cultured on SIM (shoot induction medium).

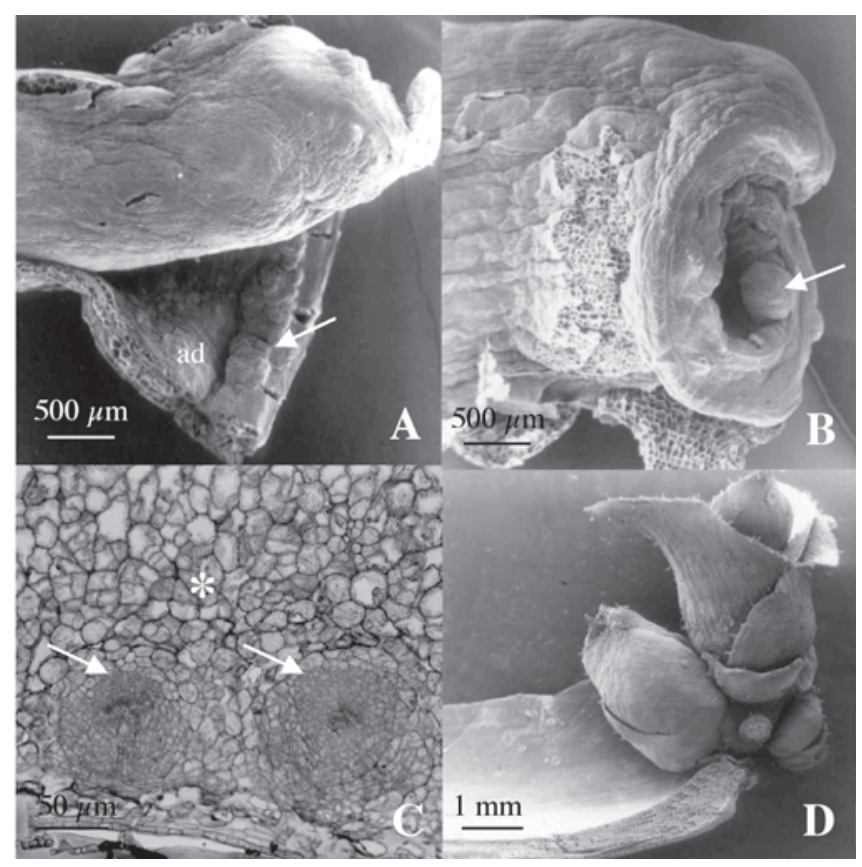

Figure 2. Morphology of pineapple leaves cultivated on SIM (shoot induction medium). A,B,D = SEM and $\mathrm{C}=$ transverse section. (A) 6 days: swelling (arrow) on the adaxial surface (ad) of the curled leaf. The leaf was longitudinally sectioned for better examination. (B) 9 days: note the protuberance on the adaxial surface (arrow) of the leaf. (C) 9 days: note the meristematic cell centres of the protuberances (arrows), and the divided parenchyma cells (*) of the leaf. (D) 15 days: newly formed shoots. 
Levels of endogenous hormones: Auxins. The IAA levels measured in the basal leaf segments are shown in figure $3 \mathrm{~A}$. In the first 3 days for SIM, a 3-fold reduction was observed, following this its concentration increased about 15 -fold $\left(6^{\text {th }}\right.$ day) to then fluctuate at a relatively high level. Even so, the quantification of IAA in the basal portion of leaves cultured on $\mathrm{CM}$ showed an almost continuous decrease, except for the period between the $6^{\text {th }}$ and the $9^{\text {th }}$ days.

Cytokinins. BA and iP were the only cytokinins detected. Their contents, measured in the basal leaf segments, are shown in figures $3 \mathrm{~B}$ and $3 \mathrm{C}$. The $\mathrm{BA}$ content reached its maximum on the $6^{\text {th }}$ day of culture, 28 times higher in relation to 0 day, whereas in the control experiment its concentration was always comparatively lower. The highest concentration of iP was found in the leaf base cultured for 3 days, about 500 times more than the initial value ( 0 day), after which it decreased over time, except for the $9^{\text {th }}$ day. In contrast, the control experiment always showed lower levels of iP. Isopentenyladenine was the only natural cytokinin measured that had been induced in response to experimental treatment. Zeatin, ZR and iPR were never observed.

IAA/cytokinin balance. Basal leaf segments of pineapple showed the lowest IAA/cytokinin ratio during the first 3 days of culture (table 1) due to a large increase in the cytokinin level, caused mainly by an iP increase (about $96 \%$ of total). The ratio obtained for the segments of the leaves cultured on $\mathrm{CM}$ in the same period also showed a reduction, but not with the same intensity. At 15 days, the balance reached similar high values between control and treated leaf segments.

Table 1. Endogenous auxin/cytokinins (IAA/Cks) balance in basal segments of pineapple leaves at 0, 3, 6, 9 and 15 days of culture on SIM (shoot induction medium) or CM (control medium). Cks mean the sum of iP and BA.

\begin{tabular}{lccccc}
\hline \multicolumn{5}{c}{ IAA/Cks } \\
& 0 & 3 & 6 & 9 & 15 \\
\hline $\mathrm{CM}$ & 4.42 & 0.31 & 0.47 & 0.77 & 1.30 \\
$\mathrm{SIM}$ & 4.42 & 0.01 & 0.63 & 0.35 & 1.33 \\
\hline
\end{tabular}

\section{DISCUSSION}

Many stimuli are communicated across the plant body by plant hormones, which consequently play an important role in diverse aspects of plant growth and development. At a cellular level, auxin affects division, expansion and
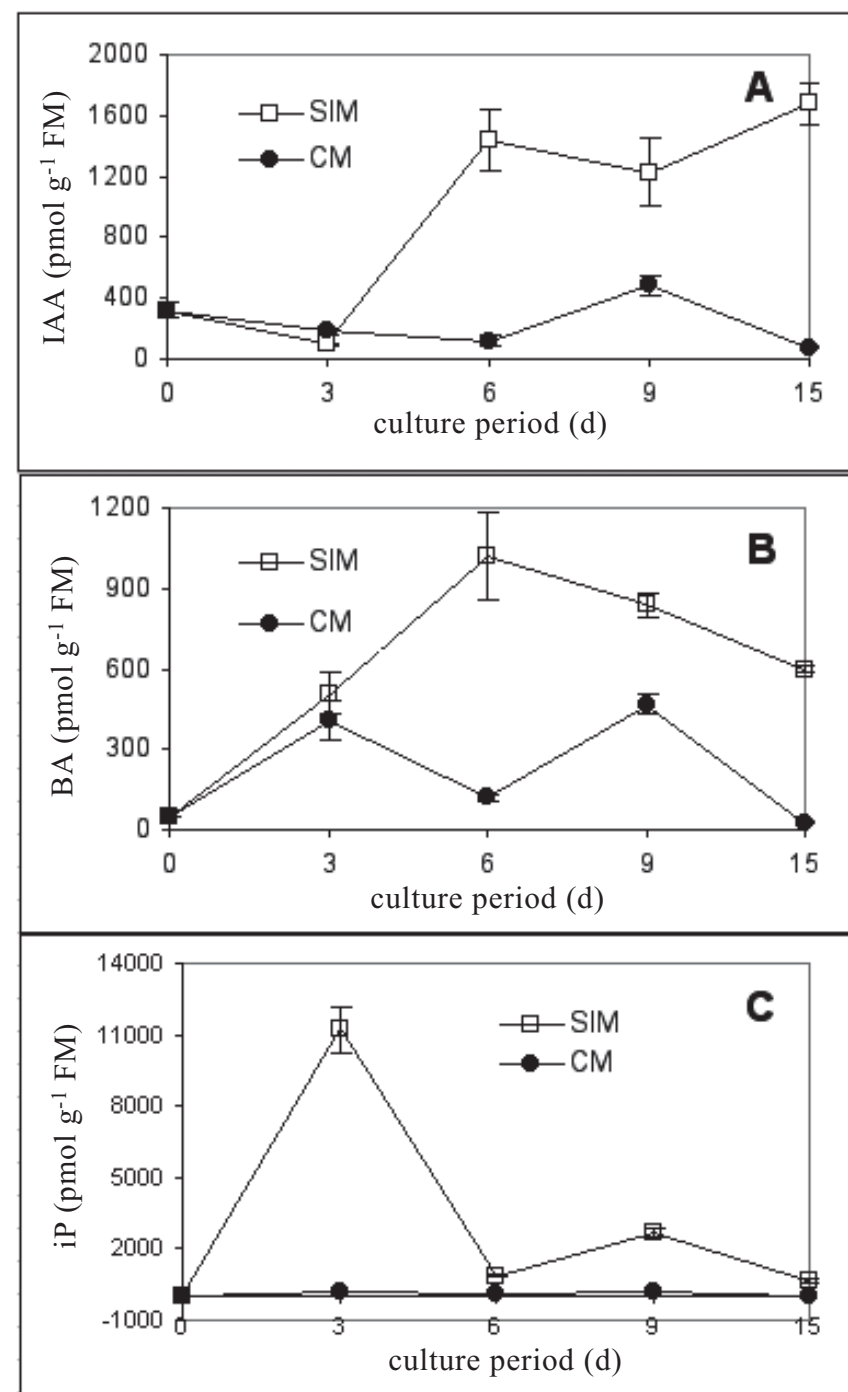

Figure 3. Endogenous levels of IAA (A), BA (B) and iP (C) in basal segments of pineapple leaves at $0,3,6,9$ and 15 days of culture on SIM (shoot induction medium) or CM (control medium). Vertical bars represent standard deviation $(\mathrm{n}=4)$.

differentiation. Cytokinins are necessary, in concert with auxin, for cell division at G1-S and G2-M transitions in a variety of cultured plant cells as well as in planta. Progression through the cell cycle is central to cell proliferation and fundamental to the growth and development of higher plants (Stals and Inzé, 2001).

Our results showed that uptake of BA and NAA by pineapple leaves cultured on SIM had consequences for the endogenous IAA and iP levels, and the organogenic response. It is important to highlight that mother-plants which provided the leaves for all experiments were cultured on a medium containing BA. Thus, the levels of BA found in the control leaves might be related to absorption from the medium and accumulation in the mother-plants. 
A similar mechanism was observed in in vitro cultured leaves of two Petunia hybrida genetic lines, which differed in their shoot organogenic response to exogenous BA (Auer et al., 1999). The difference was attributed to the distinct BA uptakes and metabolism, which subsequently affected the accumulation of iP and iPR, and the activity of cytokinin oxidase in the early stages of shoot development (Auer et al., 1999). The contents of these isoprenoid cytokinins (iP and iPR) in the leaf explants of the highly petunia shoot organogenic line, increased 1.7-fold during the shoot induction phase and underwent an additional 2.6-fold cytokinin increase, correlated with the shift from induction to the shoot development phase (Auer et al., 1999).

The endogenous IAA/cytokinin ratio of the pineapple basal leaf region reached the lowest value on the third day, mainly due to an increase in the iP level. These findings suggest that the induction phase may occur in the first 3 days of culture in pineapple leaves. Only specific target cells in the basal portion of the leaf, capable of receiving morphogenetic stimuli such as a reduced endogenous auxin/ cytokinin ratio, could enter into an organogenically determined pathway which will form the protuberance. Lakshmanan et al. (1997) noted that the cytokinin (BA) treatment is required during the induction period of six days for fully competent cells to enter into a caulogenically determined state in leaf explants of Garcinia mangostana.

In plant tissues, competent cells are considered as those cells which respond to external signals to enter a specific developmental pathway (Meins and Binns, 1979). In this way, the cells of the basal portion of the pineapple leaves cultured on SIM are the competent ones because they responded to the exogenous auxin/cytokinin balance beginning the cell division process. Valdés et al. (2001) reported the occurrence of a decreasing basal-apical gradient in morphogenetic potential of the cotyledon of Pinus pinea, which was correlated with a decrease of endogenous cytokinin levels in the apical portion of this organ.

Lo et al. (1997), using leaf discs of African violets cultured on SIM, observed cell divisions in the epidermis. According to these authors, cell division was essential for giving rise to target cells which were responsive to exogenous hormones, and for the formation of cell division centres, the precursors of adventitious shoots. Histological studies revealed that pineapple leaf protuberances have an endogenous origin, and that they are originate through cell division centres or meristematic cell centres. Intense cell division in the leaf parenchyma was also observed. Meijer and Murray (2001) suggest that cell division and morphogenesis are intimately interconnected, and the elaboration and execution of developmental programs require proper control of the cell-division cycle. Cell cycle control of particular divisions in local domains appears to be essential, and perhaps a driving force for the establishment of specific structures.

Molecular mechanisms underlying shoot organogenesis in vitro have also shown the importance of cytokinin in this process. A cytokinin signalling pathway leading to the formation of adventitious shoots involves a receptor, CKI1, that confers to the cell the ability to sense endogenous cytokinin triggering shoot organogenesis (Sugiyama, 1999). This author further states that if CKI1 determines the sensitivity of a cell to a shoot-inducing signal of cytokinin, a possibility arises that the competence for shoot organogenesis may directly reflect the activity level of the CKIIgene. Cary et al. (2001) described Arabidopsis thaliana mutants with increased organ regeneration, i.e., these mutants showed an enhanced shoot development at a sub-optimal cytokinin level. They argue that these mutants are more competent to respond to hormonal signals, since they have a mutation in a gene designated to increased organ regeneration (IERI). In normal plant development, IRE genes may down-regulate the competency of vegetative tissue to respond to those hormonal signals involved in shoot and root organogenesis (Cary et al., 2001).

In conclusion, the present study showed that the uptake of BA and NAA from the medium by pineapple leaf, represented an essential requirement, causing an increase of endogenous iP and IAA levels which appear to be involved in the shoot organogenesis process. The high iP content found on the $3^{\text {rd }}$ day may be required for the induction of protuberances which subsequently formed shoots.

Acknowledgments: This work was supported by the Fundação de Amparo à Pesquisa do Estado de São Paulo FAPESP (Proc. 99/02660-9) and Conselho Nacional de Desenvolvimento Científico e Tecnológico - CNPq (Proc. 300732/93-7; 3001776/83).

\section{REFERENCES}

Auer CA, Motyka V, Brezinová A, Kamínek M (1999) Endogenous cytokinin accumulation and cytokinin oxidase activity during shoot organogenesis of Petunia hybrida. Physiol. Plant. 105:141-147.

Carneiro LA, Araújo RFG, Brito GJM, Fonseca MHPB, Costa A, Crocomo OJ, Mansur E (1998) In vitro regeneration 
from leaf explants of Neoregelia cruenta (R. Graham) L.B. Smith, an endemic bromeliad from Eastern Brazil. Plant Cell Tissue Organ Cult. 55:79-83.

Cary A, Uttamchandani SJ, Smets R, Van Onckelen HA, Howell SH (2001) Arabidopsis mutants with increased organ regeneration in tissue culture are more competent to respond to hormonal signals. Planta 213:700-707.

Christianson ML, Warnick DA (1985) Temporal requirement for phytohormone balance in the control of organogenesis in vitro. Develop. Biol. 112:494-497.

Johansen DA (1940) Plant Microtechnique, McGraw-Hill Book, New York.

Karnovsky MJ (1965) A formaldehyde-glutaraldehyde fixative of high osmolality for use in electron microscopy. J. Cell. Biol. 27:137-138.

Knudson L (1946) A new nutrient solution for germination of orchid seed. Amer. Orch. Soc. Bull. 15:214-217.

Kraus JE, Arduin M (1997) Manual Básico de Métodos em Morfologia Vegetal. Editora Universidade Rural, Seropédica.

Lakshmanan P, Ng SK, Loh CS, Goh CJ (1997) Auxin, cytokinin and ethylene differentially regulate specific developmental states associated with shoot bud morphogenesis in leaf tissues of mangosteen (Garcinia mangostana L.) cultured in vitro. Plant Cell Physiol. 38:59-64.

Lo KH, Giles KL, Sawhney VK (1997) Histological changes associated with acquisition of competence for shoot regeneration in leaf discs of Saintpaulia ionantha $\mathrm{x}$ confusa hybrid (African violet) cultured in vitro. Plant Cell Rep. 16:421-425.

Maldiney R, Leroux B, Sabbagh I, Sotta B, Sossountzov L, Miginiac E (1986) A biotin-avidin-based enzyme immunoassay to quantify three phytohormones: auxin, abscisic acid and zeatin-riboside. J. Immunol. Met. 90:151-158.

Meijer M, Murray JAH (2001) Cell cycle controls and the development of plant form. Curr. Opin. Plant Biol. 4:44-49.

Meins FJr, Binns NA (1979) Cell determination in plant development. BioScience 29:221-225.
Mercier H, Kerbauy GB (1992) In vitro multiplication of Vrisea fosteriana. Plant Cell Tissue Organ Cult. 30:247-249.

Mercier H, Kerbauy GB (1993) Micropropagation of Dyckia macedoi - an endangered endemic brazilian bromeliad. Bot. Gard. Microprop. News 1:70-72.

Murashige T, Skoog F (1962) A revised medium for rapid growth and bioassays with tobacco tissue culture. Physiol. Plant. 15:73-497.

O'Brien TP, Feder N, McCully ME (1965). Polychromatic staining of plant cell walls by toluidine blue $O$. Protoplasma 59:368-373.

Pelèse F, Megnegneau B, Sotta B, Sossountzov L, Caboche M, Miginiac E (1989) Hormonal characterisation of a nonrooting NAA tolerant tobacco mutant by immunoenzymic method. Plant Physiol. 89:86-92.

Silveira M (1989) Preparo de amostras biológicas para microscopia eletrônica de varredura. In: Souza W (ed), Manual sobre Técnicas Básicas em Microscopia Eletrônica, pp. 71-90. Sociedade Brasileira de Microscopia Eletrônica, Rio de Janeiro.

Skoog F, Miller CO (1957) Chemical regulation of growth and organ formation in plant tissues cultivated in vitro. Symp. Soc. Exp. Biol. 11:118-131.

Sotta B, Pilate G, Pelèse F, Sabbagh I, Bonnet M, Maldiney R (1987) An avidin-biotin solid phase ELISA for femtomole isopentenyladenine and isopentenyladenosine measurements in HPLC purified plant extracts. Plant Physiol. 84:571-573.

Stals H., Inzé D (2001) When plant cells decide to divide. Trends Plant Sci. 6: 359-364.

Sugiyama M (1999) Organogenesis in vitro. Curr. Opin. Plant Biol. 2:61-64.

Teng W-L (1997) An alternative propagation method of Ananas through nodule culture. Plant Cell Rep. 16:454-457.

Valdés AE, Ordás RJ, Fernández B, Centeno ML (2001) Relationships between hormonal contents and the organogenic response in Pinus pinea cotyledons. Plant Physiol. Biochem. 39:377-384.

Wakasa K (1989) Pineapple (Ananas comosus L. Merr.). In: Bajaj YPS (ed), Biotechnology in Agriculture and Forestry, Vol 5, pp. 13-29. Springer Verlag, Berlin. 